\title{
FAKTOR FUNDAMENTAL DAN MAKRO EKONOMI YANG MENENTUKAN HARGA SAHAM PERUSAHAAN MAKANAN DAN MINUMAN DI BURSA EFEK INDONESIA
}

\author{
Hendro Sasongko \\ Universitas Pakuan, Bogor, Indonesia \\ Email: hendro.sasongko@unpak.ac.id
}

\begin{abstract}
The research intends to determine the stock price from fundamental (Current Ratio [CR], Return on Assets [ROA], Earning Per Share [EPS], Debt to Equity Ratio [DER]) and macroeconomic factors (Inflation Rate) of food and beverage companies on the Indonesia Stock Exchange. This type of research is a verification study with an explanatory survey method. The type of data used is secondary data with a sampling method that is purposive sampling. There are thirteen sample companies that use panel data regression analysis methods, with regression models that meet the classical assumption test. Based on the results of the study note that simultaneously $C R, R O A, E P S, D E R$, and Inflation variables determine the stock price. Partially, CR does not determine the stock price, ROA partially determines the stock price positively and significantly. EPS partially determines stock prices positively and significantly. DER partially does not determine stock prices. The inflation rate partially determines stock prices negatively. The implication of this research is that companies really need to pay attention to the level of profitability because the ratio is very influential on investor perceptions. In addition, macroeconomics must also be considered because it affects the perception of investors in the company's position.
\end{abstract}

\section{Keywords: fundamental factors, macroeconomic, stock prices}

\section{ABSTRAK}

Penelitian yang bermaksud untuk menentukan harga saham dari faktor fundamental (Current Ratio [CR], Return on Assets [ROA], Earning Per Share [EPS], Debt to Equity Ratio [DER]) dan makro ekonomi (Tingkat Inflasi) pada perusahaan makanan dan minuman di Bursa Efek Indonesia. Jenis penelitian ini adalah penelitian verifikatif dengan metode explanatory survey. Jenis data yang digunakan adalah data sekunder dengan metode penarikan sampel yaitu purposive sampling. Terdapat tiga belas perusahaan yang menjadi sampel yang menggunakan metode analisis regresi data panel, dan model regresi yang memenuhi uji normalitas data. Penelitian ini memberikan hasil bahwa dalam uji simultan variabel CR, ROA, EPS, DER, dan Inflasi menentukan harga saham. Secara parsial CR tidak menentukan harga saham, ROA secara parsial menentukan harga saham secara positif dan signifikan. EPS secara parsial menentukan harga saham secara positif dan signifikan. DER secara parsial tidak menentukan harga saham. Tingkat inflasi secara parsial menentukan harga saham secara negatif. Implikasi dari penelitian ini bahwa perusahaan sangat perlu memperhatikan tingkat profitabilitas karena rasio tersebut sangat berpengaruh terhadap persepsi investor. Selain itu, makro ekonomi harus juga diperhatikan karena berdampak pada persepsi investor terhadap posisi perusahaan.

Kata kunci: faktor fundamental, makro ekonomi, harga saham

\section{KETERANGAN ARTIKEL}

Riwayat Artikel: diterima: 1 Februari 2020; direvisi: 10 April 2020; disetujui: 29 April 2020

Klasifikasi JEL: G00, G11, 011

Cara Mensitasi: Sasongko, H. (2020). Faktor Fundamental dan Makro Ekonomi yang Menentukan Harga Saham Perusahaan Makanan dan Minuman di Bursa Efek Indonesia. JIMFE (Jurnal IImiah Manajemen Fakultas Ekonomi), 6(1), 1-12. https://doi.org/10.34203/jimfe.v6i1.1935

Copyright@2020. JIMFE (Jurnal Ilmiah Manajemen Fakultas Ekonomi) Universitas Pakuan 


\section{PENDAHULUAN}

Persaingan industri di Indonesia semakin ketat, terlebih spesifik perusahaan makanan serta minuman yang terdaftar pada Bursa Efek Indonesia. Berdasarkan data Kemenperin tahun 2017, industri makanan serta minuman nasional mencatatkan pertumbuhan sebanyak 7,19 persen di triwulan II. Ditinjau asal perkembangan realisasi investasi, sektor industri makanan serta minuman buat penanaman kapital dalam negeri (PMDN) triwulan III tahun 2017 mencapai Rp27,92 triliun. Capaian tadi turut beperan pada kontribusi manufaktur terhadap Produk Domestik Bruto (PDB) industri nonmigas yang mencapai 34,17 persen atau tertinggi dibandingkan sektor lainnya. Triwulan II tahun 2018 laju pertumbuhan perusahaan kuliner dan minuman mencapai 12,70 persen serta berkontribusi sampai 35,39 persen terhadap PDB industri nonmigas.

Berkaitan dengan kinerja tersebut, perusahaan yang mencatatkan sahamnya di
Bursa Efek Indonesia (BEI) memiliki harga saham yang merupakan cerminan dari kinerja perusahaan. Harga saham merupakan salah satu hal utama yang mendasari para investor untuk membeli saham. Harga saham adalah harga yang terjadi di pasar bursa pada saat tertentu yang ditentukan oleh pelaku pasar dan ditentukan oleh permintaan dan penawaran saham yang bersangkutan di pasar modal (Jogiyanto, 2016).

Kesehatan suatu perusahaan dapat dilihat melalui analisis kinerja keuangan yang bertujuan untuk memberikan gambaran tentang nilai perusahaan tersebut. Pengukuran kinerja dapat dilakukan dengan menggunakan rasio keuangan.

Berikut adalah gambaran kinerja perusahaan ataupun fundamental perusahaan pada industri makanan dan minuman di Bursa Efek Indonesia serta tingkat inflasi Indonesia yang menggambarkan makro ekonomi.

Tabel 1. Nilai Fundamental dan Makro Ekonomi pada Industri Makanan dan Minuman

\begin{tabular}{lrrrrr}
\hline \multicolumn{1}{c}{ Keterangan } & $\mathbf{2 0 1 4}$ & $\mathbf{2 0 1 5}$ & $\mathbf{2 0 1 6}$ & $\mathbf{2 0 1 7}$ & \multicolumn{1}{c}{$\mathbf{2 0 1 8}$} \\
\hline Harga Saham & $\mathrm{Rp} 3.200$ & $\mathrm{Rp} 2.623$ & $\mathrm{Rp} 3.353$ & $\mathrm{Rp} 3.653$ & $\mathrm{Rp} 4.037$ \\
\hline Current Ratio & 199,45 & 211,14 & 233,34 & 248,07 & 264,43 \\
\hline Return on Assets & 9,78 & 8,58 & 11,03 & 10,72 & 9,40 \\
\hline Earnings Per Share & 193,02 & 252,03 & 215,47 & 178,37 & 183,17 \\
\hline Debt to Equity Ratio & 113,36 & 103,88 & 97,60 & 82,19 & 86,75 \\
\hline Inflasi & 6,42 & 6,38 & 3,53 & 3,81 & 3,20 \\
\hline
\end{tabular}

Sumber: BEI dan BPS, data diolah 2020

Berdasarkan tabel terdapat kesenjangan antara data dengan teori. Pada tahun 2015, Current Ratio (CR) mengalami kenaikan dari 199,45 persen menjadi 211,14 persen, sedangkan pada tahun 2015 mengalami penurunan dari Rp3.200 menjadi Rp2.623. Keadaan seperti ini menggambarkan bahwa rasio ini tidak sesuai dengan teorinya yaitu akan bergerak searah dengan harga saham.

Current Ratio (CR) yang rendah akan mengurangi minat investor untuk menanamkan modalnya di perusahaan tadi, sehingga akan menurunkan harga saham.
Teori tersebut didukung dengan adanya penelitian terdahulu yang dilakukan Sutapa (2018) menyatakan bahwa Current Ratio secara parsial berpengaruh signifikan dan positif terhadap harga saham.

Berdasarkan tabel terdapat kesenjangan anatara data dan teori. Pada tahun 2017, Return on Assets (ROA) mengalami penurunan dari 11,03 persen menjadi 10,72 persen, sedangkan pada tahun 2017 harga saham mengalami kenaikan dari Rp3.353 menjadi Rp3.653. Begitupun pada tahun 2018, Return on Assets (ROA) mengalami penurunan dari 
10,72 persen menjadi 9,40 persen, sedangkan pada tahun 2018 harga saham mengalami kenaikan dari Rp3.653 menjadi Rp4.037. Hal ini bertentangan dengan teori yang menyatakan bahwa Return on Assets (ROA) akan bergerak searah dengan harga saham di bursa.

Semakin besar Return on Assets (ROA), maka semakin baik kemajuan perusahaan untuk mendapatkan keuntungan dan investor akan tertarik untuk menanamkan modalnya. Tetapi sebaliknya, jika nilai ROA semakin turun, perusahaan dianggap kurang efisien dalam memanfaatkan aset untuk kegiatan bisnisnya. Teori tersebut didukung dalam penelitian sebelumnya yang menyatakan bahwa Return on Assets berpengaruh positif dan signifikan terhadap harga saham (Kartikasari, 2019).

Berdasarkan tabel, terdapat kesenjangan antara data dengan teori. Pada tahun 2015, Earning Per Share (EPS) mengalami kenaikan dari Rp193,02 menjadi Rp252,03, sedangkan harga saham tahun 2015 mengalami penurunan dari Rp3.200 menjadi Rp2.623. Begitupun tahun 2016 terjadi penurunan dari Rp252,03 menjadi Rp215,47, sedangkan pada tahun 2016 harga saham mengalami kenaikan dari Rp2.623 menjadi Rp3.353. Hal ini bertentangan dengan teori yang menyatakan bahwa Earning per Share (EPS) akan bergerak searah atau sejalan dengan harga saham.

Hasil kajian mengenai Earning per Share seperti Alipudin dan Oktaviani (2016); dan Sutapa (2018) bahwa Earning per Share (EPS) yang tinggi menggambarkan perusahaan akan mampu memberikan keuntungan yang tinggi untuk para investor. Jika Earning per Share (EPS) rendah, perusahaan akan memberikan tingkat keuntungan yang rendah untuk para investor. Semakin tinggi Earning per Share (EPS), maka harga saham akan mengalami kenaikan. Earning per Share (EPS) berpengaruh positif dan signifikan terhadap harga saham.
Berdasarkan tabel, terdapat kesenjangan antara data dengan teori. Tahun 2015, Debt to Equity Ratio (DER) mengalami penurunan dari 113,36 persen menjadi 103,88 persen, sedangkan tahun 2015 harga saham mengalami penurunan dari Rp3.200 menjadi Rp2.623. Begitupun tahun 2018, Debt to Equity Ratio (DER) naik dari 82,19 persen menjadi 86,75 persen, sedangkan pada tahun 2018 harga saham mengalami kenaikan dari Rp3.653 menjadi Rp4.037. Keadaan ini bertentangan dengan teori yang menyatakan bahwa Debt to Equity Ratio (DER) bergerak tidak searah dengan harga saham.

Kajian mengenai Debt to Equity Ratio (DER) pada harga saham seperti Daniel (2015); Amrah dan Elwisam (2018), bahwa Debt to Equity Ratio (DER) secara parsial berpengaruh negatif dan signifikan terhadap harga saham. Debt to Equity Ratio (DER) yang tinggi, maka harga saham perusahaan akan mengalami penurunan karena jika perusahaan menerima keuntungan, kemungkinan perusahaan akan menggunakan keuntungan tersebut untuk membayar utang daripada membagikan keuntungan tersebut kepada investor dalam bentuk dividen.

Berdasarkan tabel terdapat kesenjangan antara data dengan teori. Tahun 2015, tingkat inflasi mengalami penurunan dari 6,42 persen menjadi 6,38 persen, sedangkan tahun 2015 harga saham mengalami penurunan dari Rp3.200 menjadi Rp2.623. Tahun 2017 tingkat inflasi mengalami kenaikan dari 3,53 persen menjadi 3,81 persen, sedangkan tahun 2017 harga saham mengalami kenaikan dari Rp3.353 ke Rp3.653. Keadaan ini tidak mencerminkan teori yang menyatakan bahwa tingkat inflasi akan bergerak berlawanan dengan harga saham.

Kajian mengenai inflasi terhadap harga saham dilakukan oleh Harsono et al (2018); Suselo, et al (2015); dan Murni (2013) yang menyatakan bahwa tingkat inflasi berpengaruh negatif dan signifikan terhadap harga saham. Inflasi merupakan suatu 
Hendro Sasongko: Faktor Fundamental dan ...

keadaan dimana terjadi kenaikan harga secara umum dan terus menerus. Peningkatan tingkat inflasi merupakan sinyal negatif bagi para investor di pasar modal. Inflasi yang tinggi kemungkinan akan menurunkan return yang akan didapatkan oleh investor.

Penelitian ini membahas faktor-faktor fundamental yang dapat menentukan persepsi investor terhadap suatu perusahaan, selain faktor fundamental, makro ekonomi juga dapat menentukan penilaian investor terhadap posisi perusahaan tersebut. Kekhasan dari penelitian ini adalah dari sisi faktor fundamental dan makro ekonomi yang digunakan, serta periode dan jumlah perusahaan yang akan diteliti. Selain itu, kondisi saat ini yang berbeda yang menuntut setiap perusahaan untuk terus meningkatkan kinerjanya dalam keadaan persaingan yang tinggi.

\section{KAJIAN LITERATUR DAN PENGEMBANGAN HIPOTESIS}

Sutapa (2018), Sajiyah (2016), Valintino, dan Sularto (2013) menyatakan bahwa current ratio berpengaruh positif dan signifikan terhadap harga saham. Perusahaan yang memiliki nilai Current Ratio yang tinggi maupun rendah dapat menggambarkan kemampuannya dalam membayar utang, maka dampaknya adalah terhadap minat investasi investor di perusahaan. Semakin tinggi Current Ratio, maka menggambarkan kemampuan perusahaan yang tinggi untuk membayar utang jangka pendek. Tetapi Current Ratio yang sangat tinggi pula menggambarkan kinerja manajemen yang kurang baik atas dalam mengelola asetnya. Kelebihan pada aset lancar seharusnya dipergunakan untuk membayar dividen, membayar utang jangka panjang, atau untuk investasi yang bisa membuat taraf kembalian lebih.

Sitanggang (2012) menyatakan bahwa Return on Assets (ROA) adalah rasio yang menggambarkan kemampuan perusahaan memperoleh keuntungan dari investasi aset perusahaan. Semakin besar Return on Assets maka semakin baik, karena tingkat pengembalian (return) semakin besar.

Pernyataan tersebut didukung oleh penelitian yang dilakukan oleh Arkan (2016), Al Qaisi, Tahtamouni, dan Aq-Qudah (2016), Amrah dan Elwisam (2018), Sajiyah (2016) menyatakan bahwa Return on Assets berpegaruh positif dan signifikan terhadap harga saham.

Kasmir (2016) menyatakan bahwa Earning Per Share adalah keuntungan yang diperoleh perusahaan per lembar saham guna membandingkan laba dari berbagai entitas dan guna membandingkan laba suatu entitas ketika terjadi perubahan dalam struktur kapital. Tingginya Earning Per Share (EPS) mengindikasikan bahwa perusahaan dapat memberikan taraf laba pada para investor. Jika Earning Per Share (EPS) rendah, perusahaan akan menyampaikan tingkat laba yang rendah kepada para pemegang saham, sedangkan jika Earning Per Share (EPS) meningkat, harga saham akan mengalami kenaikan.

Pernyataan tersebut didukung penelitian yang dilakukan Alipudin dan Oktaviani (2016), dan Sutapa (2018), Suselo, et al (2015), Pratama, dkk (2019) yang menyatakan bahwa Earning Per Share (EPS) berpengaruh positif serta signifikan terhadap harga saham.

Debt to Equity Ratio (DER) menggambarkan perbandingan total utang dengan ekuitas saham biasa yang dipergunakan dalam membiayai total aset perusahaan (Gitman dan Zutter, 2015). Kajian mengenai Debt to Equity Ratio telah diteliti oleh Daniel (2015), Amrah dan Elwisam (2018) yang menyatakan bahwa Debt to Equity Ratio berpengaruh negatif dan signifikan terhadap harga saham serta Debt To Equity Ratio merupakan perbandingan utang dan ekuitas pada pendanaan perusahaan dan memberikan kemampuan kapital sendiri perusahaan dalam memenuhi kewajibannya. Debt to equity ratio yang tinggi, memungkinkan harga saham perusahaan tersebut akan turun harganya 
dikarenakan saat perusahaan mendapakan keuntungan, keuntungan tersebut digunakan untuk membayar utangnya dibandingkan untuk membaginya kepada para pemegang saham.

Murni (2013) menyatakan bahwa inflasi merupakan suatu kejadian yang menunjukkan kenaikan tingkat harga secara umum dan berlangsung secara terus menerus. Sinyal negatif akan didapatkan oleh investor bagi perusahaan saat adanya inflasi yang semakin tinggi yang akan menyebabkan berkurangnya keuntungan (return) yang akan diperoleh oleh investor.

Pernyataan tersebut didukung oleh penelitian yang dilakukan oleh oleh Harsono, dkk (2018), dan Suselo, dkk (2015) yang menyatakan bahwa tingkat inflasi berpengaruh negatif dan signifikan terhadap harga saham.

Berdasarkan latar belakang, kajian teori, penelitian terdahulu, dan kerangka berfikir, hipotesis penelitian ini adalah:

Hipotesis 1: Current ratio menentukan harga saham perusahaan makanan dan minuman di
Bursa Efek Indonesia.

Hipotesis 2: Return on Assets menentukan harga saham perusahaan makanan dan minuman di Bursa Efek Indonesia.

Hipotesis 3: Earning per Shares menentukan harga saham perusahaan makanan dan minuman di Bursa Efek Indonesia.

Hipotesis 4: Debt to Equity Ratio menentukan harga saham perusahaan makanan dan minuman di Bursa Efek Indonesia.

Hipotesis 5: Inflasi menentukan harga saham perusahaan makanan dan minuman di Bursa Efek Indonesia.

Hipotesis 6: Current ratio, Return on Assets, Earning per Shares, Debt to Equity Ratio dan Inflasi menentukan harga saham perusahaan makanan dan minuman di Bursa Efek Indonesia.

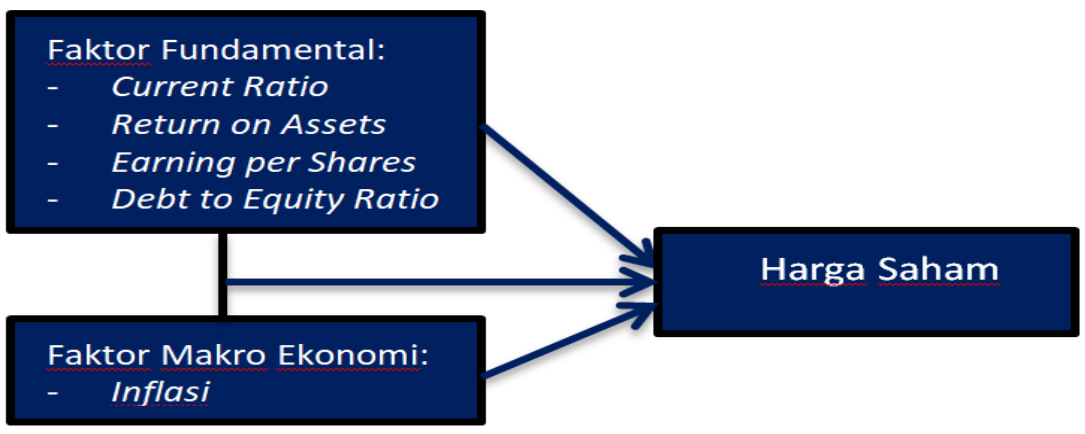

Sumber: Data diolah (2020)

Gambar 1. Kerangka Pemikiran

\section{METODE PENELITIAN}

Sampel penelitian ini yaitu perusahaan makanan dan minuman yang terdaftar di Bursa Efek Indonesia periode 2014-2018 yang memenuhi kriteria dengan metode purposive sampling diantaranya adalah perusahaan yang memiliki kelengkapan data variabel, didapatkan 13 perusahaan, dengan jenis penelitiannya adalah verifikatif dan data yang digunakan adalah data kuantitatif. 


\section{Operasionalisasi Variabel \\ Current Ratio (CR)}

Rumusan untuk mencari Current Ratio (CR) adalah dengan membandingkan total asset lancer/jangka pendek dengan liabilitas jangka pendek. Berikut adalah rumusan CR:

$$
C R=\frac{\text { Current ratio }}{\text { Current Liability }}
$$

\section{Debt to Equity Ratio (DER)}

Rumusan untuk mencari Debt to Equity Ratio (DER) adalah dengan membandingkan total utang dengan ekuitasnya. Berikut adalah rumusan DER:

$$
D E R=\frac{\text { Total debt }}{\text { Total Equity }}
$$

\section{Return on Assets (ROA)}

Rumusan untuk mencari Return on Asset adalah dengan membandingkan laba bersih setelah pajak dengan total asetnya. Berikut adalah rumusan ROA:

$$
R O A=\frac{\text { Net income }}{\text { Total Assets }}
$$

\section{Earning per Share (EPS)}

Rumusan untuk mencari Earning per Share adalah dengan membandingkan laba bersih dengan jumlah saham beredar. Berikut adalah rumusan EPS:

$$
E P S=\frac{\text { Net income }}{\text { Shares Outstanding }}
$$

\section{Inflasi}

Berikut adalah rumusan untuk mendapatkan nilai inflasi:

$$
I_{N F n}=\frac{I H K n-I H K_{n-1}}{H K_{n-1}} \times 100 \%
$$

\section{Harga Saham}

Harga saham yang digunakan adalah harga saham pada saat penutupan akhir tahun 2014 sampai dengan tahun 2018.

\section{HASIL DAN PEMBAHASAN Uji Normalitas}

Tujuan digunakannya uji ini adalah untuk mencari apakah data yang akan digunakan memiliki nilai residual terdistribusi normal atau tidak. Nilai signifikansi yang berdistribusi normal jika lebih dari 0,05. Berikut adalah hasil dari uji normalitas:

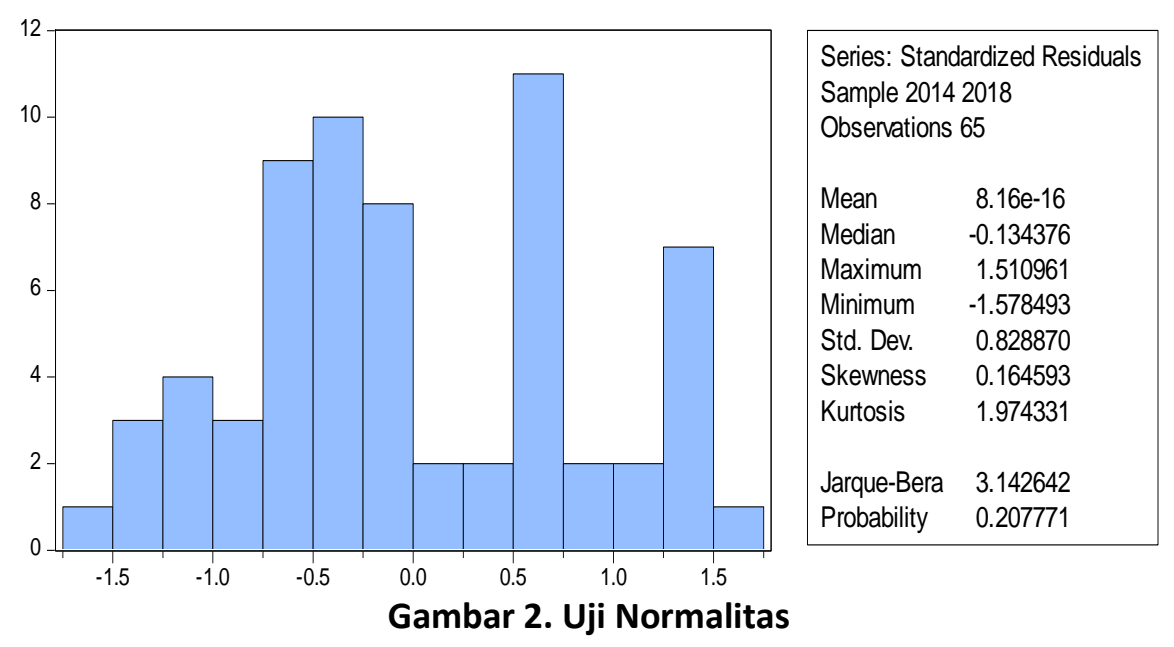

Sumber: Data diolah (2020)

Tabel di atas menggambarkan nilai signifikansi yang diperoleh sebesar 0,207771. Nilai siginifikanso tersebut lebih dari taraf yang disyaratkan yaitu 0,05 , maka nilai residual data telah normal. Oleh karena itu, model penelitian telah dapat memenuhi asumsi normalitas dan dapat dilanjutkan. 
Uji Hipotesis

Uji Determinasi (R2)

Uji determinasi (R2) bertujuan untuk menjelaskan pengaruh atau nilai sumbangan dari seluruh variabel independen terhadap variabel dependen dalam suatu model. Nilai R2 yang lebih dekat kepada angka sempurna (100 persen) mempunyai arti bahwa semua variabel independen dalam model mampu menjelaskan pengaruhnya terhadap variabel dependen.

Hasil uji menggambarkan bahwa nilai koefisien determinasi sebesar 0,566798, menunjukkan bahwa variabel independen yang terdiri dari Current Ratio (CR), Return On Assets (ROA), Earning Per Share (EPS), Debt to Equity Ratio (DER), dan Tingkat Inflasi mampu menjelaskan sebesar 56,67 persen pengaruhnya terhadap harga saham, sedangkan sisanya sebesar 43,33 persen kemungkinan ditentukan oleh variabel lain yang tidak ada dalam model penelitian ini. Nilai Adjusted R Square sebesar 0,521612. Hal ini menunjukkan sumbangan pengaruh variabel nilai Current Ratio (CR), Return on Assets (ROA), Earning Per Share (EPS), Debt to Equity Ratio (DER), dan Tingkat Inflasi terhadap Harga saham sebesar 52,16 persen.

Uji F

Hasil pengujian untuk menguji pengaruh semua variabel independen terhadap variabel dependen adalah sebagai berikut:

Tabel 2. Uji F

\begin{tabular}{llll}
\hline \multicolumn{4}{l}{ Weighted Statistics } \\
\hline R-squared & 0.566798 & Mean dependent var & 1.175182 \\
\hline Adjusted R-squared & 0.521612 & S.D. dependent var & 0.349828 \\
\hline S.E. of regression & 0.266051 & Sum squared resid & 4.176192 \\
\hline F-statistic & 10.33047 & Durbin-Watson stat & 1.839225 \\
\hline Prob(F-statistic) & 0.000000 & & \\
\hline
\end{tabular}

Sumber: Data diolah (2020)

Tabel di atas diperoleh nilai uji Fstatistik sebesar 10,33047 dengan probabilitas 0,000000 . Nilai Probabilitas F $(0,000000<$ 0,05). Hal ini menggambarkan bahwa Current Ratio (CR), Return on Assets (ROA), Earning Per Share (EPS), Debt to Equity Ratio (DER), dan Tingkat Inflasi secara bersama-sama atau simultan menentukan harga saham pada perusahaan makanan dan minuman yang terdaftar di Bursa Efek Indonesia.

\section{Uji t}

Hasil pengujian untuk menguji masing-masing variable independen terhadap variable dependen dengan taraf nyata 0,05 adalah sebagai berikut:

Tabel 3. Uji t

\begin{tabular}{crrrr}
\hline Variable & Coefficient & Std. Error & t-Statistic & Prob. \\
\hline CR & -0.039409 & 0.050535 & -0.779839 & 0.4386 \\
\hline ROA & 3.261085 & 0.767346 & 4.249825 & 0.0001 \\
\hline EPS & 0.094699 & 0.026361 & 3.592367 & 0.0007 \\
\hline DER & 0.066065 & 0.122479 & 0.539399 & 0.5916 \\
\hline INFASI & -14.53384 & 3.081989 & -4.715732 & 0.0000 \\
C & 7.398665 & 0.325153 & 22.75440 & 0.0000 \\
\hline
\end{tabular}

Sumber: Data diolah (2020) 
Hendro Sasongko: Faktor Fundamental dan ...

Berdasarkan tabel uji $\mathrm{t}$, menunjukkan bahwa Current Ratio (CR) dengan nilai koefisien negatif sebesar $-0,039409$ dan nilai probabilitas sebesar 0,4386 . Nilai probabilitas uji $\mathrm{t}(0,4386>0.05)$. Hal tersebut menunjukkan bahwa Current Ratio (CR) tidak menentukan besarnya harga saham pada perusahaan makanan dan minuman yang terdaftar di Bursa Efek Indonesia.

Return on Assets (ROA) dengan nilai koefisien regresi positif sebesar 3,261085 dan probabilitasnya sebesar 0,0001 . Nilai probabilitas uji t $(0,0001<0.05)$. Hal tersebut menggambarkan bahwa Return on Assets (ROA) menentukan nilai harga saham secara positif pada perusahaan makanan dan minuman yang terdaftar di Bursa Efek Indonesia.

Earning Per Share (EPS) dengan nilai koefisien regresi positif sebesar 0.094699 dan probabilitasnya sebesar 0,0007. Nilai probabilitas uji t $(0,0007<0,05)$. Hal tersebut menggambarkan bahwa Earning Per Share (EPS) menentukan nilai harga saham secara positif pada perusahaan makanan dan minuman yang terdaftar di Bursa Efek Indonesia.

Debt to Equity Ratio (DER) dengan nilai koefisien regresi positif sebesar 0,066065 dan probabilitasnya sebesar 0,5916. Nilai probabilitas uji t $(0,5916>0.05)$. Hal tersebut menggambarkan bahwa Debt to Equity Ratio (DER) tidak menentukan nilai harga saham pada perusahaan makanan dan minuman yang terdaftar di Bursa Efek Indonesia.

Tingkat Inflasi dengan nilai koefisien regresi negatif sebesar $-14,53384$ dan probabilitasnya sebesar 0,0000 . Nilai probabilitas uji t $(0,0000<0,05)$. Hal tersebut menunjukkan bahwa Tingkat Inflasi menentukan nilai harga saham, tetapi secara negatif pada perusahaan makanan dan minuman yang terdaftar di Bursa Efek Indonesia.

\section{Pembahasan dan Implikasi Penelitian}

Faktor Fundamental Terhadap Harga Saham Perusahaan Makanan dan Minuman di Bursa Efek Indonesia

Hasil penelitian Current Ratio (CR) tidak menentukan nilai harga saham pada perusahaan makanan dan minuman yang terdaftar di BEI. Hal ini menggambarkan walaupun perusahaan memiliki nilai $\mathrm{CR}$ yang tinggi, tetapi hanya berfungsi untuk mengukur kemampuan perusahaan dalam melunasi utang jangka pendeknya, dengan begitu perusahaan dapat menggunakan asset jangka pendeknya untuk membayar utang jangka pendeknya. Maka tingginya CR tidak tidak menjadi penilaian investor karena $C R$ yang tinggi mengindikasikan bahwa kas yang masuk tertimbun sehingga mengakibatkan kas tidak dimanfaatkan untuk mengoptimalkan aset perusahaan, dengan begitu menyebabkan CR tidak dapat menentukan harga saham.

Hasil penelitian ini sejalan dengan yang telah dilakukan sebelumnya oleh Kartikasari (2019), Pratama, Azizah dan Nurlaily (2019), dan Rahmadewi dan Abundanti (2018), Hatta dan Dwiyanto (2012) yang menyatakan bahwa CR tidak berpengaruh terhadap harga saham.

Return on Assets menentukan harga saham secara positif pada perusahaan makanan dan minuman yang terdaftar di Bursa Efek Indonesia. ROA yang tinggi, menggambarkan bahwa perusahaan mampu untuk memperoleh keuntungan yang tinggi dan merupakan sinyal positif bagi para investor untuk menanamkan modalnya pada perusahaan. Sebaliknya, jika ROA semakin rendah, menggambarkan kinerja perusahaan dianggap kurang efisien dalam penggunaan aset dalam operasionalnya.

Hasil penelitian ini konsisten dengan penelitian yang dilakukan oleh Arkan (2016), Al Qaisi, Tahtamouni, dan Al-Qudah (2016), Kartikasari (2019), Amrah dan Elwisam (2018), Sajiyah (2016) yang menyatakan bahwa Return on Assets berpegaruh positif signifikan terhadap harga saham. 
Earning Per Share menentukan harga saham secara positif pada perusahaan makanan dan minuman yang terdaftar di Bursa Efek Indonesia. Earning Per Share (EPS) yang tinggi mengindikasikan bahwa perusahaan tersebut dapat memberikan tingkat return yang tinggi kepada pemegang saham, tetapi sebaliknya jika rendah maka kemampuan perusahaan dalam memberikan return yang rendah pula kepada para pemegang saham. Sinyal Earning Per Share yang tinggi akan dapat respon positif dari investor sehingga harga saham akan naik.

Hasil penelitian ini sejalan dengan yang telah dilakukan oleh Alipudin dan Oktaviani (2016), dan Sutapa (2018) yang menyatakan bahwa Earning Per Share (EPS) berpengaruh positif dan signifikan terhadap harga saham.

Hasil pengujian menggambarkan DER tidak menentukan harga saham. Menurut Brigham dan Houston (2016) sesuai dengan teori pendekatan Modigliani \& Miller yang berpendapat bahwa struktur modal yang kurang relevan tidak menentukan besarnya nilai perusahaan. Para investor pun akan tetap menginvestasikan dananya yang mereka miliki pada perusahaan walaupun tingkat utangnya tinggi ataupun rendah.

Hasil penelitian ini sejalan dengan yang telah dilakukan oleh Sutapa (2018), Lestari dan Suryantini (2019), Priliyastuti dan Stella (2017), Valintino dan Lana (2013), Pratama, Azizah dan Nurlaily (2019) yang menyatakan bahwa DER tidak berpengaruh terhadap harga saham.

Makro Ekonomi Terhadap Harga Saham Perusahaan Makanan dan Minuman di Bursa Efek Indonesia

Tingkat inflasi menentukan harga saham tetapi secara negatif pada perusahaan makanan dan minuman yang terdaftar di Bursa Efek Indonesia.

Hasil penelitian ini sejalan dengan Murni (2013) bahwa inflasi adalah keadaan dimana terjadinya kenaikan harga secara umum dan dalam jangka panjang. Adanya nilai inflasi yang tinggi merupakan sinyal negatif untuk para investor. Tingkat inflasi yang tinggi mengakibatkan keuntungan investor akan berkurang. Tanda negatif menggambarkan efek yang saling berlawanan antara tingkat inflasi dengan harga saham, saat tingkat inflasi naik, maka harga saham mengalami bearish.

Hasil penelitian ini sejalan dengan yang telah dilakukan oleh Suselo, dkk (2015), Halima (2019) yang menyatakan bahwa tingkat inflasi berpengaruh negatif dan signifikan terhadap harga saham.

Implikasinya adalah perusahaan sangat perlu memperhatikan tingkat profitabilitas karena rasio tersebut sangat berpengaruh terhadap persepsi investor. Selain itu, makro ekonomi harus juga diperhatikan karena berdampak terhadap persepsi investor dalam posisi perusahaan.

Faktor Fundamental dan Makro Ekonomi yang Menentukan Harga Saham Perusahaan Makanan dan Minuman di Bursa Efek Indonesia

Current Ratio, Return on Assets, Earning Per Share, Debt to Equity Ratio, dan tingkat inflasi secara simultan atau bersama-sama dapat menentukan nilai harga saham pada perusahaan makanan dan minuman di Bursa Efek Indonesia. Hal ini menunjukkan bahwa jika variabel $C R, R O A, E P S, D E R$, dan Inflasi secara simultan mengalami kenaikan maka harga saham akan mengalami kenaikan juga.

Hasil penelitian ini sejalan dengan yang telah dilakukan oleh Suselo, dkk (2015), dan Julia dan Diyani (2016), Wardani dan Andriani (2019) dan Halima (2019) yang menyatakan bahwa Current Ratio, Return On Assets, Earning Per Share, Debt to Equity Ratio, dan tingkat inflasi secara simultan berpengaruh terhadap harga saham.

\section{PENUTUP}

Berdasarkan hasil penelitian diperoleh bahwa secara parsial Current Ratio tidak menentukan harga saham, ROA menentukan harga saham 
Hendro Sasongko: Faktor Fundamental dan ...

secara positif dan signifikasn, EPS menentukan harga saham secara positif dan signifikan, sedangkan DER tidak menentukan harga saham, dan Inflasi menentukan harga saham tetapi secara negatif dan signifikan pada perusahaan makanan dan minuman di Bursa Efek Indonesia.

Harga saham merupakan cerminan daripada investor karena yang menentukan harga saham naik atau turun adalah suatu persepsi daripada investor itu sendiri. Artinya, dalam penelitian ini investor lebih fokus untuk memperhatikan faktor fundamental dari sisi profitabilitas, yaitu ROA dan EPS. Investor lebih memperhatikan return yang diperoleh oleh perusahaan makanan dan minuman yang diperoleh yang merupakan hasil operasional perusahaan tersebut untuk dibagikan kepada investor dalam bentuk dividen. Selain daripada itu, tentunya faktor makro ekonomi yang diwakili oleh tingkat inflasi juga menentukan dalam terciptanya harga saham perusahaan makanan dan minuman. Investor melihat tingkat inflasi merupakan faktor yang juga berpengaruh terhadap tingkat return yang akan diperoleh.

Peneliti selanjutnya yang berminat meneliti mengenai faktor fundamental dan makro ekonomi, sebaiknya menambahkan variabel-variabel lain selain seperti Dividend Payout Ratio (DPR), Return On Equity (ROE), Return On Investment (ROI), Debt to Asset Ratio (DAR), dan faktor-faktor lain dari makro ekonomi seperti tingkat kurs, pertumbuhan ekonomi, tingkat pendapatan, dan lain-lain sebagai faktor yang dapat menentukan nilai harga saham suatu perusahaan. Sektor atau industri yang berbeda dapat juga untuk diteliti lebih lanjut dengan jumlah data yang lebih banyak seperti sub sektor semen, kontruksi, property dan real estate, dan lain-lain.

\section{REFERENSI}

Alipudin, A., \& Oktaviani, R. (2016). Pengaruh EPS, ROE, ROA dan DER terhadap Harga Saham pada Perusahaan Sub Sektor Semen Yang Terdaftar Di Bei. JIAFE

\section{(Jurnal Ilmiah Akuntansi Fakultas Ekonomi), 2(1), 1-22. https://doi.org/10.34204/jiafe.v2i1.521}

Amrah, R. Y., \& Elwisam. (2018). Pengaruh Current Ratio, Return on Assets, Debt to Equity Ratio, dan Total Assets Turnover terhadap Harga Saham pada Perusahaan LQ45 Tahun 2013-2015. Jurnal IImu Manajemen, 14(2), 26-42.

Arkan, T. (2016). The Importance of Financial Ratios in Predicting Stock Price Trends: A Case Study in Emerging Markets. Zeszyty Naukowe Uniwersytetu Szczecińskiego Finanse Rynki Finansowe Ubezpieczenia, 1(1), 13-26. https://doi.org/10.18276/frfu.2016.7901

Brigham, Eugene $F$ and Joel F. Houston. (2014). Fundamental of Financial Management, 14th Edition. Mason: South-Western Cengange Learning.

Brigham, E. F, dan Houston. (2016). Fundamental of Financial Management: Dasar-Dasar Manajemen Keuangan. Edisi 11. Jakarta: Salemba Empat.

Comley, P. (2015). Inflation Matters. London: Pete Comley.

Daniel. (2015). Pengaruh Faktor Internal Terhadap Harga Saham Pada Perusahaan LQ 45 yang Terdaftar di Bursa Efek Indonesia. Jurnal EMBA. Vol.3 No.3 Sept. 2015, Hal.863-876. ISSN: 2303-11.

Darmadji, T. dan Fakhrudin. (2012). Pasar Modal di Indonesia. Edisi Ketiga. Jakarta: Salemba Empat.

Fahmi, I. (2015). Pengantar Pasar Modal. Bandung: Alfabeta.

Fouzan Al Qaisi, Dr. Asem Tahtamouni, Dr. Mustafa AL-Qudah. (2016). Factors Affecting the Market Stock Price - The Case of the Insurance Companies Listed in Amman Stock Exchange. International Journal of Business and Social Science. Vol. 7, No. 10; October 2016, 81-90.

Gitman, Lawrence J. (2015). Principles of Managerial Finance. 12th Edition. 
Boston: Pearson Education, Inc.

Halima, J., Amin, M., \& Mawardi, M. C. (2018). E-JRA Vol. 08 No. 10 Agustus 2019 Fakultas Ekonomi dan Bisnis Universitas Islam Malang. E-Jra, 07(10), 119-131.

Harsono, A. R., \& Wonokinasih, S. (2018). Pengaruh Inflasi, Suku Bunga, Dan Nilai Tukar Rupiah terhadap Indeks Harga Saham Gabungan (Studi pada Bursa Efek Indonesia Periode 2009-2013). Jurnal Administrasi Bisnis, 60(2), 102-110.

Hatta, Atika J dan Bambang Sugeng D. (2012). The Company Fundamental Factors And Systematic Risk in Increasing Stock Price. Journal of Economics, Business, and Accountancy Ventura. Volume 15, No. 2 pages $245-256$. ISSN 2087-3735

Horne, James C. and John M, Wachowicz. (2013). Fundamentals of Financial Management, 13th Edition. United Kingdom: Pearson Education.

Jauharia Hatta, A., \& Sugeng Dwiyanto, B. (2012). The Company Fundamental Factors and Systematic Risk in Increasing Stock Price. Journal of Economics, Business, and Accountancy I Ventura, 15(2), 245. https://doi.org/10.14414/jebav.v15i2.7 8

Julia, T. T., \& Diyani, L. A. (2015). Pengaruh Faktor Fundamental Keuangan dan Makroekonomi terhadap Harga Saham. Jurnal Bisnis dan Komunikasi, 2(2), 109119, ISSN 2356-4385.

Jogiyanto. (2016). Teori Portofolio dan Analisis Investasi. Edisi Kesepuluh. Yogyakarta: BPFE UGM.

Kartikasari, U. (2019). Pengaruh Debt To Equity Ratio, Current Ratio, dan Return on Asset terhadap Harga Saham Perusahaan Infrastuktur Terdaftar di Bursa Efek Indonesia Periode 20082017. Manners, II(1), 41-50.

Kasmir. (2016). Analisis Laporan Keuangan. Jakarta: PT. Raja Grafindo Persada.

Lestari, I. S. D., \& Suryantini, N. P. S. (2019).
Pengaruh CR, DER, ROA, dan PER Terhadap Harga Saham pada Perusahaan Farmasi di BEI. E-Jurnal Manajemen, 8(3), 1844-1871.

McGuigan, James R., William J. Kretlow, and R. Charles Moyer. (2012). Contemporary Financial Management. Singapore: South-Western.

Murni, Asfia. (2013). Ekonomika Makro. Edisi Revisi. Bandung : PT Refika Aditama.

Natsir, M. (2014). Ekonomi Moneter dan Perbankan Sentral. Jakarta: Mitra Wacana Media.

Pratama, C. A., Devi Farah Azizah, \& Nurlaily, F. (2019). Pengaruh Return On Equity (ROE), Earning Per Share (EPS), Current Ratio (CR), dan Debt to Equity Ratio (DER) Terhadap Harga Saham. Business Administration Journal, 66(1), 10-17. administrasibisnis.studentjournal.ub.ac.i d

Priliyastuti, N., \& Stella, S. (2017). Pengaruh Current Ratio, Debt to Asset, Debt to Equity, Return on Assets, dan Price Earnings Ratio terhadap Harga Saham. Jurnal Bisnis Dan Akuntansi, 19(5), 320324.

Qaisi, Fouzan Al., et al. (2016). Factors Affecting the Market Stock Price - The Case of the Insurance Companies Listed in Amman Stock Exchange. International Journal of Business and Social Science Vol. 7, No. 10, October 2016.

Rahmadewi, P. W., \& Abundanti, N. (2018). Pengaruh EPS, PER, CR, dan ROE terhadap Harga Saham di Bursa Efek Indonesia. E-Jurnal Manajemen Universitas Udayana, 7(4), 2106. https://doi.org/10.24843/ejmunud.201 8.v07.i04.p14

Ros, Stephen A., Randolph W. Westerfield., Bradford D. Jordan. Joseph Lim \& Ruth Tan. (2013). Fundamentals Of Corporate Finance: Tenth Edition. Mc Graw Hill.

Sajiah, I. (2016). Pengaruh Current Ratio, Debt to Equity dan Return On Investment 
Terhadap Harga Saham Perusahaan Food and Baverages. Akademika, 14(1).

Sartono, Agus. (2011). Manajemen Keuangan, Teori dan Aplikasi. Edisi Kedua. Yogyakarta: UGM.

Sitanggang, J.P. (2012). Manajemen Keuangan Perusahaan. Jakarta: Mitra Wacana Media.

Sukirno, S. (2016). Teori Pengantar Makro Ekonomi. Edisi Ketiga. Jakarta: Rajawali Pers.

Suselo, D., Djazuli, A., \& Indrawati, N. K. (2015). Pengaruh Variabel Fundamental dan Makro Ekonomi terhadap Harga Saham (Studi pada Perusahaan yang Masuk dalam Indeks LQ45). Jurnal Apliaksi Manajemen, 13(1).

Sutapa, I. N. (2018). Pengaruh Rasio Dan Kinerja Keuangan Terhadap Harga Saham Pada Indeks Lq45 Di Bursa Efek Indonesia (BEI) Periode 2015-2016. KRISNA: Kumpulan Riset Akuntansi, 9(2), 11.

https://doi.org/10.22225/kr.9.2.467.11-

\section{9}

Sutrisno. (2012). Manajemen Keuangan Teori, Konsep dan Aplikasi. Yogyakarta: EKONISIA.

Valintino, R., \& Sularto, L. (2014). Pengaruh Return On Asset (ROA), Current Ratio (CR), Return On Equity (ROE), Debt to Equity Ratio (DER), dan Earning Per Share (EPS) Terhadap Harga Saham Perusahaan Manufaktur Sektor Industri Barang Konsumsi di BEl. Proceding PESAT, 5, 675-706. https://doi.org/10.1002/978111900535 3.ch21

Wardani, Dewi K dan Andarini, D. (2016). Pengaruh Kondisi Fundamental, Inflasi, dan Suku Bunga Sertifikat Bank Indonesia Terhadap Harga Saham. Jurnal Akuntansi Vol. 4 No.2 Desember 2016. ISSN : 2540-9646.

Widoatmojo, S. (2015). Pengetahuan Pasar Modal untuk Konteks Indonesia. Jakarta: PT. Elex Media Komputindo. 